\title{
KAMYANE-ZAVALLIA, THE EASTERNMOST LINEAR POTTERY CULTURE SETTLEMENT EVER EXCAVATED
}

\begin{abstract}
Kiosak D. 2017. Kamyane-Zavallia, the Easternmost Linear Pottery Culture Settlement Ever Excavated. Sprawozdania Archeologiczne 69, 253-269.

The paper presents recent field-work in south-western Ukraine. Three new sites of Linear Pottery Culture were found in the north Odessa region. The Author argues that they constitute a cluster of settlements and indicate the Neolithic colonisation of the region. One of the sites, Kamyane-Zavallia, was excavated. A typical long pit was uncovered, alongside a stone pavement and a narrow, deep trench. They could probably have formed part of a typical LPC house's layout. Ceramic imports of the Dudeşti culture revealed long-distance contacts with the farmers of Lower Danube valley.
\end{abstract}

Keywords: Neolithic, Linear Pottery Culture, agricultural colonisation, long pits, ceramic imports, Dudeşti culture

Received: 24.05.2017; Revised: 21.06.2017; Accepted: 03.07.2017

\section{INTRODUCTION}

The way Linear Pottery Culture (LPC) expanded and affected vast portions of West, Central and East Europe has been actively debated over the last 30 years (Bogucki 1988, 117; Price et al. 2001; Dolukhanov and Shukurov 2004; Dolukhanov et al. 2005). However, the reasons why its spread stopped at a certain point are still difficult to understand. 
The scope of this paper is to define and discuss the easternmost distribution of LPC according to new evidence recorded from recent surveys and excavations. They were carried out in the south-western region of present-day Ukraine on the slopes of Podillian upland where it directly faces the Great Eurasian Steppe.

The detailed study of a new excavated settlement in the easternmost part of LPC world would contribute to the interpretation of the eventual relationships between LPC farmers and the autochthonous populations already settled there (Gronenborn 1998). According to some authors, the sites at the eastern fringe could be treated as outposts of the LPC in an alien environment, as a result of the infiltration of LPC bearers into the habitat of the indigenous population (Larina et al. 1999). In contrast, they could also be similar to «classic» sites of LPC in the heart of its area and form typical micro-regions of settlement (Siedlungskammer).

Although we have reasonable knowledge of the many LPC groups west, north and south of its core area, so far archaeologist have not been attracted by the eastern LPC expansion. J. Pavuk was the first to define the peculiarities of the development of LPC to the east of Carpathians (Pavuk 1969). While the sites of south-eastern Poland were successfully included in the general European discourse on Early Neolithic (Kulczycka-Leciejewiczowa 1970; 1979; Kozłowski 1985; Kadrow 1990; Dębiec 2015), the Ukrainian LPC is still insufficiently known. The eastern "peripheral group of LPC" was defined in Soviet times (Telegin 1979; Telegin 1985; Zaharuk and Telegin 1985). At present, some "characteristic traits" of this "peripheral group" seem to derive from different methods of excavations and the interpretation of the structural and material culture remains, rather than reflect any valid differences in prehistoric reality (Lenartowicz 2013; Saile et al. 2016).

In 2011-2016 three new sites of LPC were detected in the Southern Bug valley, north Odessa region, Ukraine. Characteristic potsherds of the Notenkopf phase of LPC were collected on the surface of two sites (Syne Ozero and Gnyla Skelia). The third site, KamyaneZavallia was excavated (Kiosak 2013; 2016; Kiosak et al. 2014a; 2014b; Saile et al. 2016). It yielded abundant material of LPC and, while some finds of LPC were discovered to the east of Kamyane-Zavallia, this cluster of sites is the easternmost Siedlungskammer of LPC. It is situated some $120-150 \mathrm{~km}$ to the east of any other LPC settled micro-region previously known.

The very existence of Kamyane-Zavallia provides new data to the issue of LPC eastward expansion. Were Kamyane-Zavallia and near-by sites outposts in the alien surroundings of a local population? Were there logistical difficulties in conducting a Neolithic way of life so far away from the LPC Heimatland? Are there similarities in the material culture and ways of life that could indicate the "realtime" interaction between early farmers and autochthonous groups of Bug-Dniester culture? Is the neolithisation of Southern Ukraine connected with the LBK spread to the east and south? This paper is not intended to solve these problems decisively but presents the results of recent excavations at Kamyane-Zavallia and suggests some ways to interpret them. 


\section{THE SITES AT THE EASTERNMOST PERIPHERY OF LPC}

There are over 300 LPC sites in Western Ukraine, Moldova and Eastern Romania (Larina 1999; Okhrimenko 2009; Lenartowicz 2013). They form clusters where settlements are packed densely indicating the intense agricultural colonization of a landscape. On the other hand, finds of LPC are scarce to the east of the river Zbruch and the lower stretches of the Dniester. There are 6-7 settlements (1 site is dubious) and ca 10 single finds in this territory. As far as O. Larina reserved a name of an "eastern periphery" of LPC to the settlements of western Ukraine and Moldova (Larina 2006; 2010), we suggest the nomination of "easternmost" group for these sites situated to the east of the "eastern region".

The above-mentioned easternmost sites are as follows.

The site of Kamyane-Zavallia has been known since 1974 as a Roman Age settlement (Stanko and Smolianinova 1974). In 2011, the author recovered a few LPC finds from the site itself. The Neolithic site covers an area of over than 6,5 ha, stretching from NE to SW along the hilly first terrace of the eastern bank of Southern Bug river. In the next year, a test-trench opened up a pit of LPC that was extremely rich in bone splinters and potsherds. In 2013-2016, the site was excavated by the didactic field expedition of "I.I. Mechnikov" Odessa National University. Kamyane-Zavallia (Fig. 1: 6) is situated at $48.1996^{\circ} \mathrm{N}$ and $29.9997^{\circ} \mathrm{E}$. It is the easternmost LPC site ever excavated at present.

Mainova Balka (Fig. 1: 9) was discovered in 1976 by S.O. Dvorianinov close to Ananiev (north Odessa region, Ukraine; cf. Dvorianinov 1982). It is located east of the long gully flowing down into the Tiligul river, ca $50 \mathrm{~km}$ from Southern Bug river valley. In 1993 the area was surveyed again by I.V. Sapozhnikov and V.G. Petrenko. They found unornamented potsherds "that look similar to LPC ware" on the western bank of the same gully (Fig. 1: 10). They called the site Mainova Balka III and tentatively attributed it to LPC (Larina et al. 1999).

Moving ca $500 \mathrm{~km}$ north, in Ukrainian Polissia, two more sites were discovered during archaeological surveys: Fasova (Fig. 1: 2) and Vita Poshtova (Telegin 1979; Gaskevych 1997). The latter is the easternmost site so far discovered with LPC material. It is located on the outskirts of Kyiv, only $25 \mathrm{~km}$ from the Dnieper River course (Fig. 1: 1).

In 2016 several typical LPC potsherds were found by the author in a location known as Gnyla Skelia (Fig. 1: 7), on the terrace of the Southern Bug, 2 km south-east of KamyaneZavallia. The site yielded also many bones and chipped stone artefacts. Another site, Syne Ozero (Fig. 1: 7), was found by O.S. Peresunchak just $2 \mathrm{~km}$ to the north of Kamyane-Zavallia, on the terrace of Southern Bug, close to artificial lake "Syne Ozero". He collected typical Notenkopf-ware shards and characteristic lithic implements on the surface of the site. Two latter sites and Kamyane-Zavallia cluster together on 5-km long stretch of Southern Bug river valley forming a micro-region of LPC settlement. The cluster of sites around Zavallia could be treated as typical Siedlungskammer and, thus, could indicate a substantial degree of LPC colonisation of the particular landscape in the Southern Bug valley on the very margin of north Pontic Steppe and Podillian upland. 
Other few isolated LPC finds were collected from sites of other cultures. Several potsherds with "musical notes" decoration were found in the Bug-Dniester sites of Bazkiv Ostriv (Fig. 1: 4), Gard (Fig. 1: 8) and Gyrzheve (Fig. 1: 11) (Danilenko 1969; Tovkailo 2014; Stanko and Kiosak 2010). A typical coarseware fragment comes from Schurivtsi-Porig (Fig. 1: 5) (Gaskevych 2011). A complete vessel comes from the multi-cultural site of Dobrianka III (Fig. 1: 3) (Zaliznyak et al. 2013). Some other finds were published from several other less clear contexts (Kiosak et al. 2014a; Saile et al. 2016).

\section{EXCAVATIONS AT KAMYANE-ZAVALLIA}

At present Kamyane-Zavallia is the only excavated site located at the easternmost fringe of the LPC. The excavations carried out in 2013-2016 covered an area of 130 sqm.

The stratigraphy of the site is as follows:

1. ploughed soil: typical chernozem (black soil); $30 \mathrm{~cm}$;

2. subsoil: grey, quite homogenous; $60-80 \mathrm{~cm}$;

3. transitional layer: grey with yellow clayey inclusions; $30-40 \mathrm{~cm}$;

4. bottom layer: yellow and light-yellow clayey loess-like loam.

A Holocene soil (layers 1-2) is more than 1m thick. This phenomenon is a common feature of the region. There is high degree of bioturbation along the sequence.

\section{Features}

\section{Pit 1}

Excavation was centered on the pit discovered during the opening of a test-trench in 2012. It consists of an irregular feature, north-east/south west oriented. Most of Pit 1 was excavated during the 2012-2016 field seasons. It is at least $21 \mathrm{~m}$ long and up to 2.5 wide in some parts. The pit was firstly observed in the profile of the aforementioned grey subsoil. Pit 1 can be seen in profile starting from a depth $-70 \mathrm{~cm}$ (from conventional zero, $100-110 \mathrm{~cm}$ from the present-day surface) and we were able to find it at $90-110 \mathrm{~cm}$ of depth inside a yellowish sediment of the transitional layer in planum. The deepest point of the pit is $-187 \mathrm{~cm}$ (over $210 \mathrm{~cm}$ from the modern surface). So pit 1 has a maximal investigated depth of 1,1 m $(187-70=117 \mathrm{~cm}$ ). It was generally shallower (some $60-70 \mathrm{~cm}$ ) and the transitional layer (3) is cut by pit 1 and does not exist above the pit.

Four stratigraphic units can be identified in the filling of pit 1: D1' is grey subsoil trampled into the almost filled pit; D1 is a grey ashy dense layer filled with bones and potsherds that covers the pit like a "cap"; D2 is a dark-grey, layer that contained less finds (than D1), but the finds are not so fragmentary, there were some vessels with complete profile; $\mathrm{D} 3$ - the blackish, lucid filling of the deepest portions of the pit 1 . This stratigraphy reflects the process of pit 1 filling. It stood open for a certain time (formation of $\mathrm{D}_{3}$ ), then it was filled 


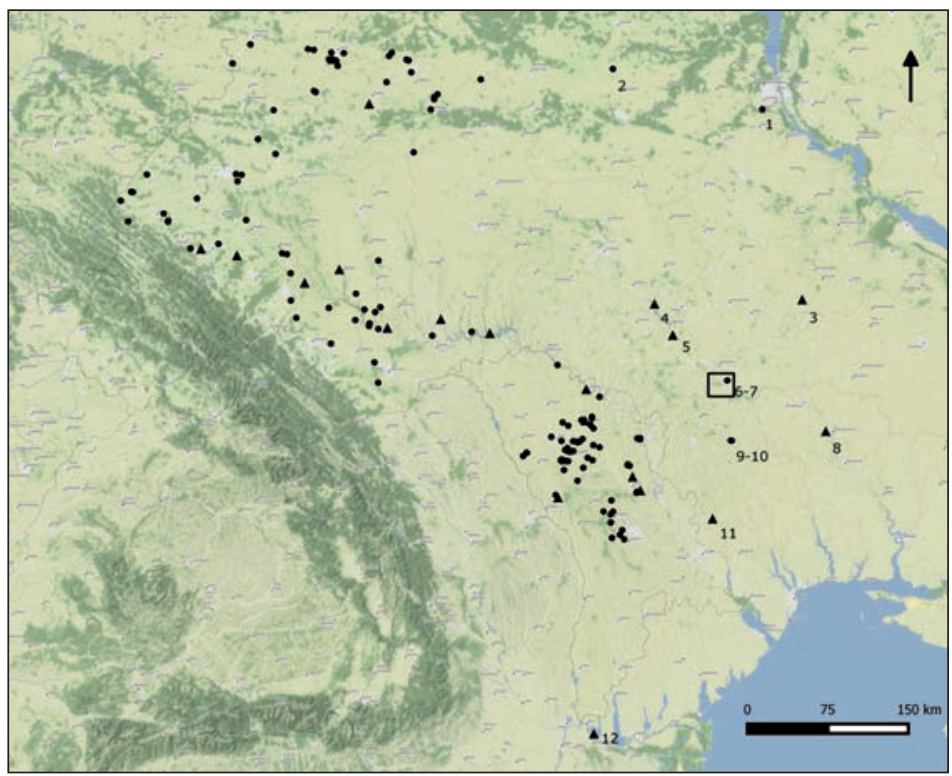

Fig. 1. Map of Linear Pottery culture sites in Ukraine and Moldova. Cirles - settlements, triangles - single finds, square - area of investigation (see Fig. 2 A). 1 - Vita Poshtova, 2 - Fasova, 3 - Dobrianka III, 4 - Bazkiv Ostriv, 5 - Schurivtsi-Porig, 6-7 - Kamyane-Zavallia, Syne Ozero, Gnyla Skelia, 8 - Gard, 9-10 - Mainova Balka, Mainova Balka III, 11 - Gyrzheve, 12 - Orlovca-Cartal

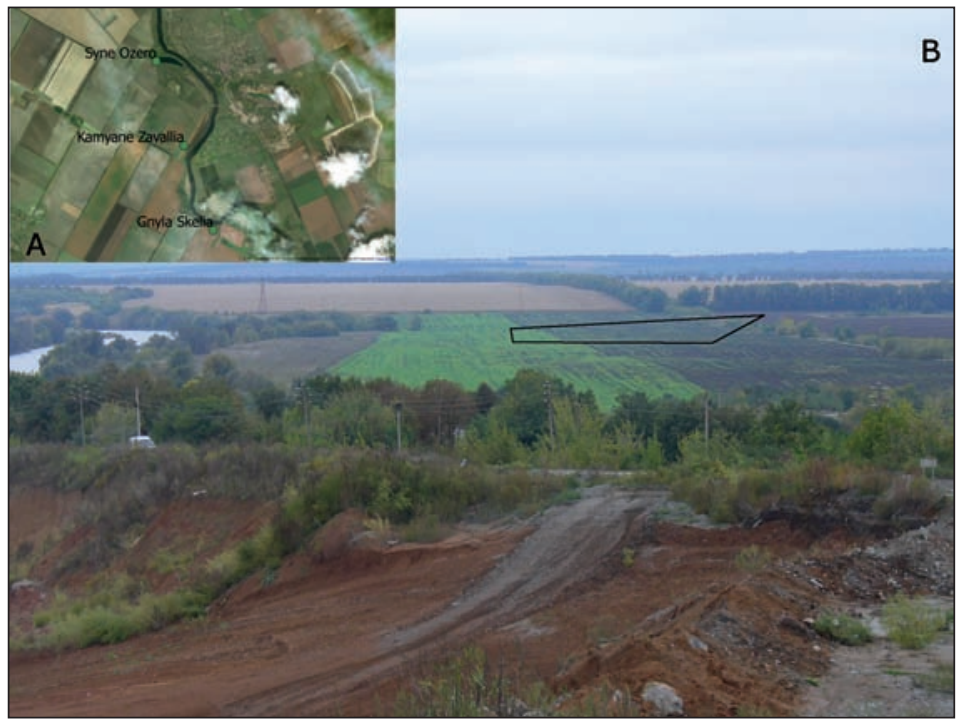

Fig. 2. A. - Area of investigation with sites of Kamyane-Zavallia, Syne Ozero and Gnyla Skelia. Topo - Bing Aerial acquired via QGIS. B - Kamyane-Zavallia, view from north-east, area of the site is marked by black line 


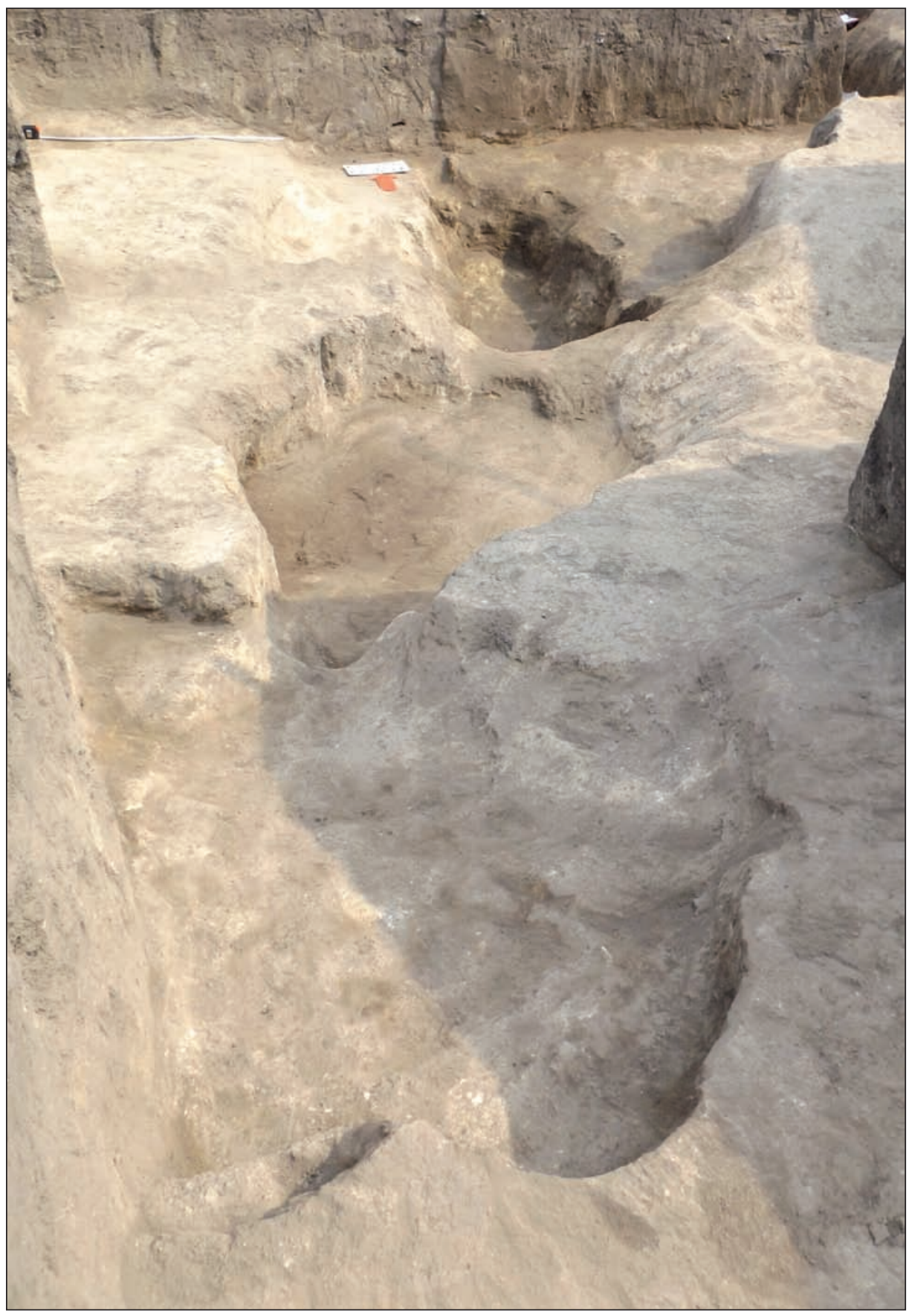

Fig. 4. Kamyane-Zavallia. Pit 1, northern part, view from south. Excavation of 2016 


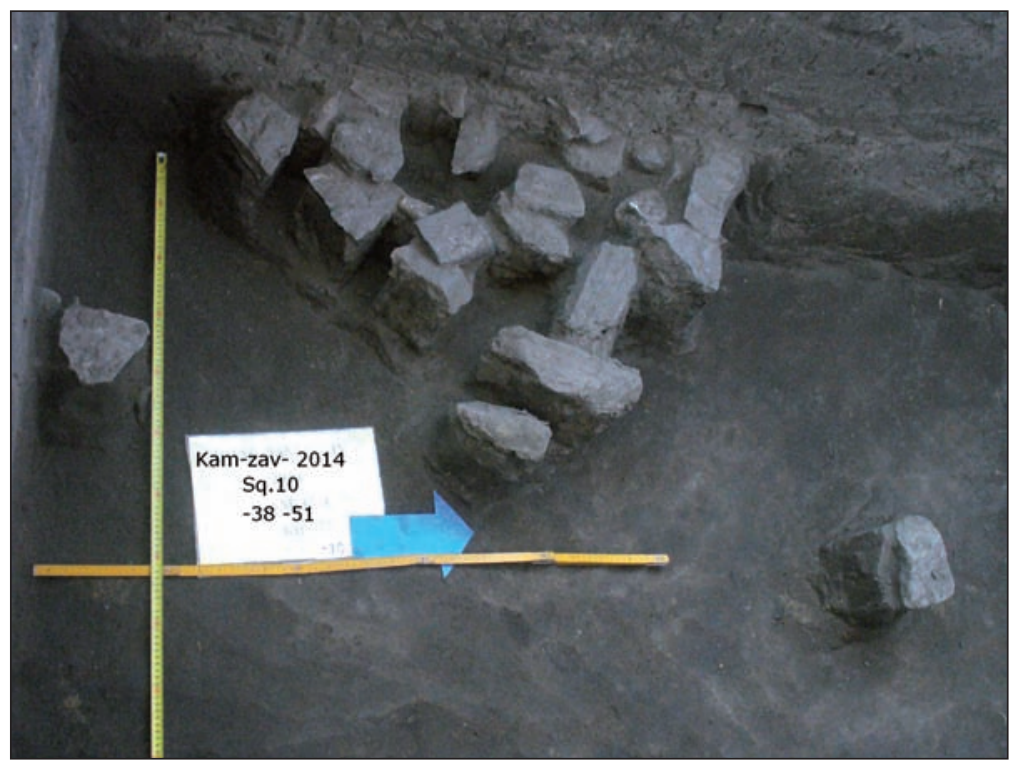

Fig. 5. Kamyane-Zavallia. Stone pavement. Excavation of 2014

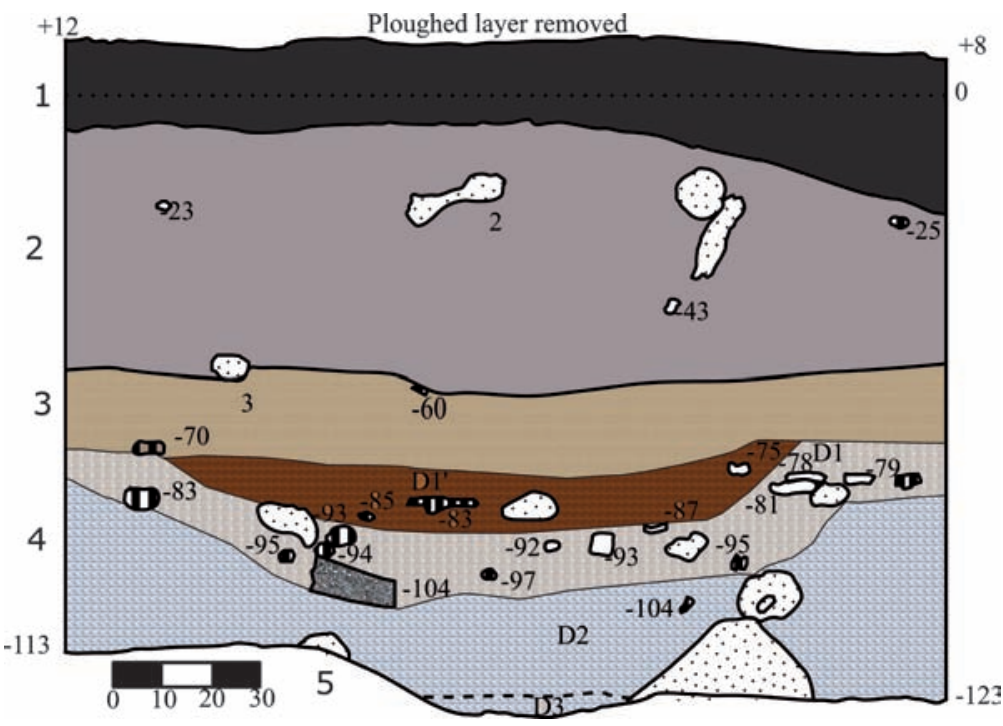

Fig. 6. Kamyane-Zavallia. Stratigraphy of Object 1 (North wall of sq. 7). Empty areas - potsherds, hashed areas - bones, grey area - stone, dotted areas - holes of bioturbation (krotovinas). 1 - ploughed layer; 2 - subsoil; 3 - carbonated layer; 4 - filling of the pit 1 with stratigraphical units D1' - grey soil, D1 - solid grey layer tightly packed with bones, potsherds etc.; D2 - dark-grey loose layer with finds of almost complete vessels; D3 - dark, lucid matter, filling of the deepest parts of the pit 1.5 - bottom layer, yellowish loam (for a detailed description, see text). Depths are from conventional zero (dotted line in the Fig. 6) 


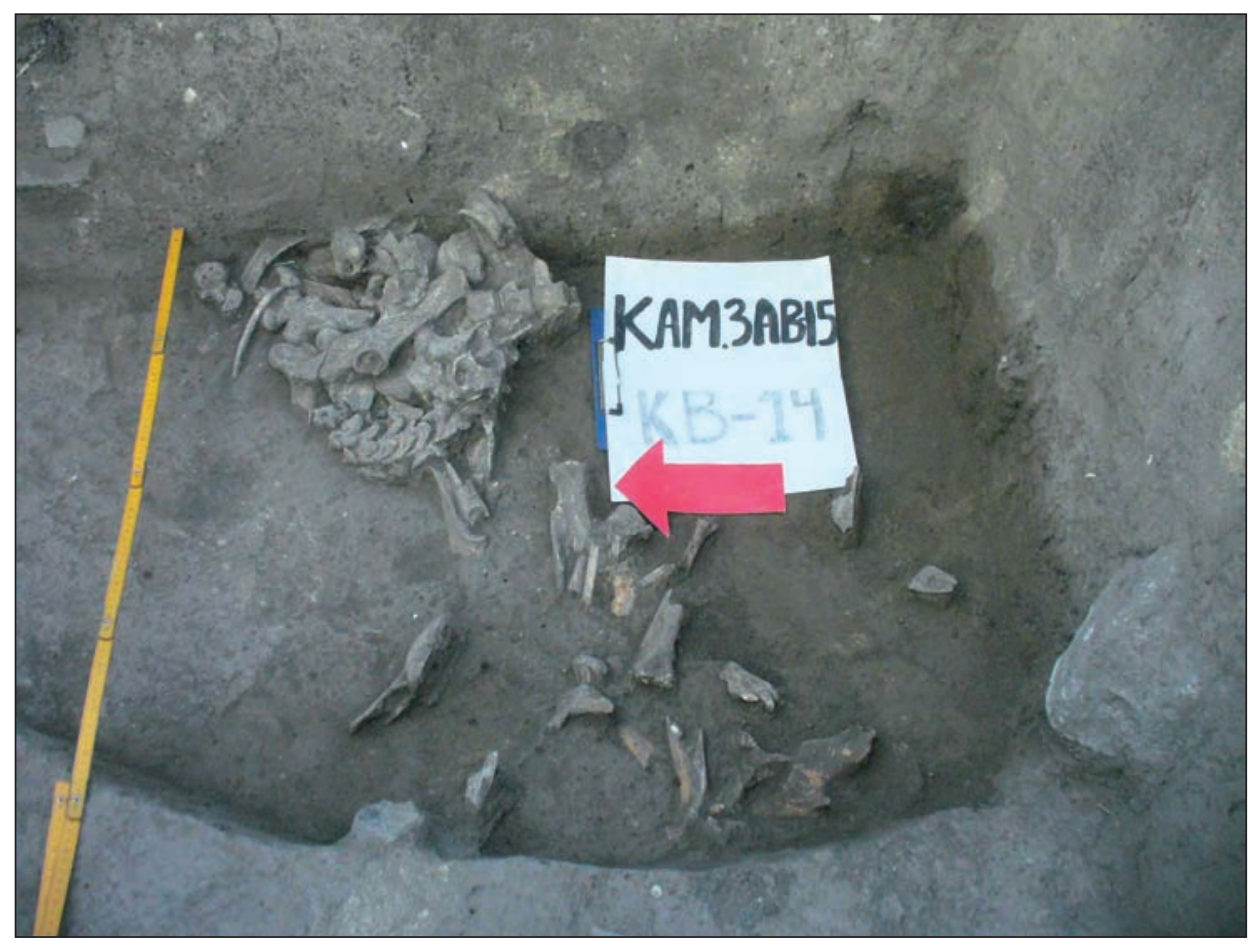

Fig. 7. Kamyane-Zavallia. Tight concentration of swine bones in pit 1, part 3. Excavation of 2015

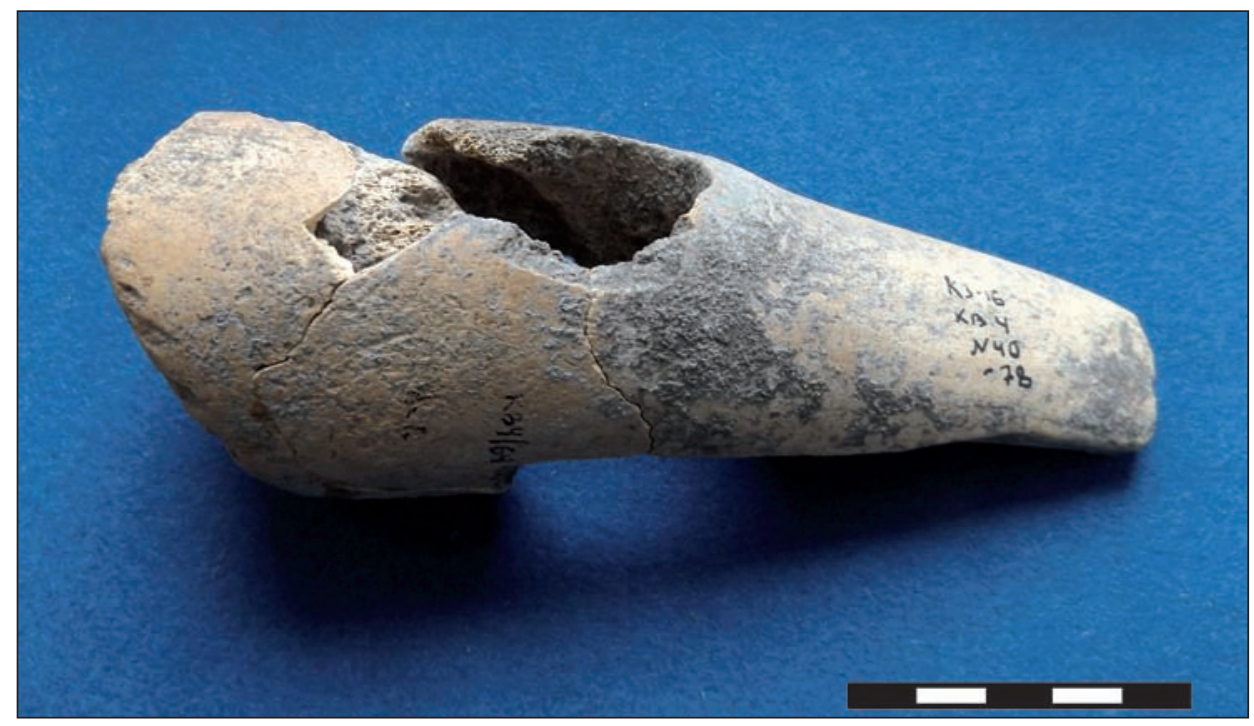

Fig. 11. Kamyane-Zavallia. Antler hammer 


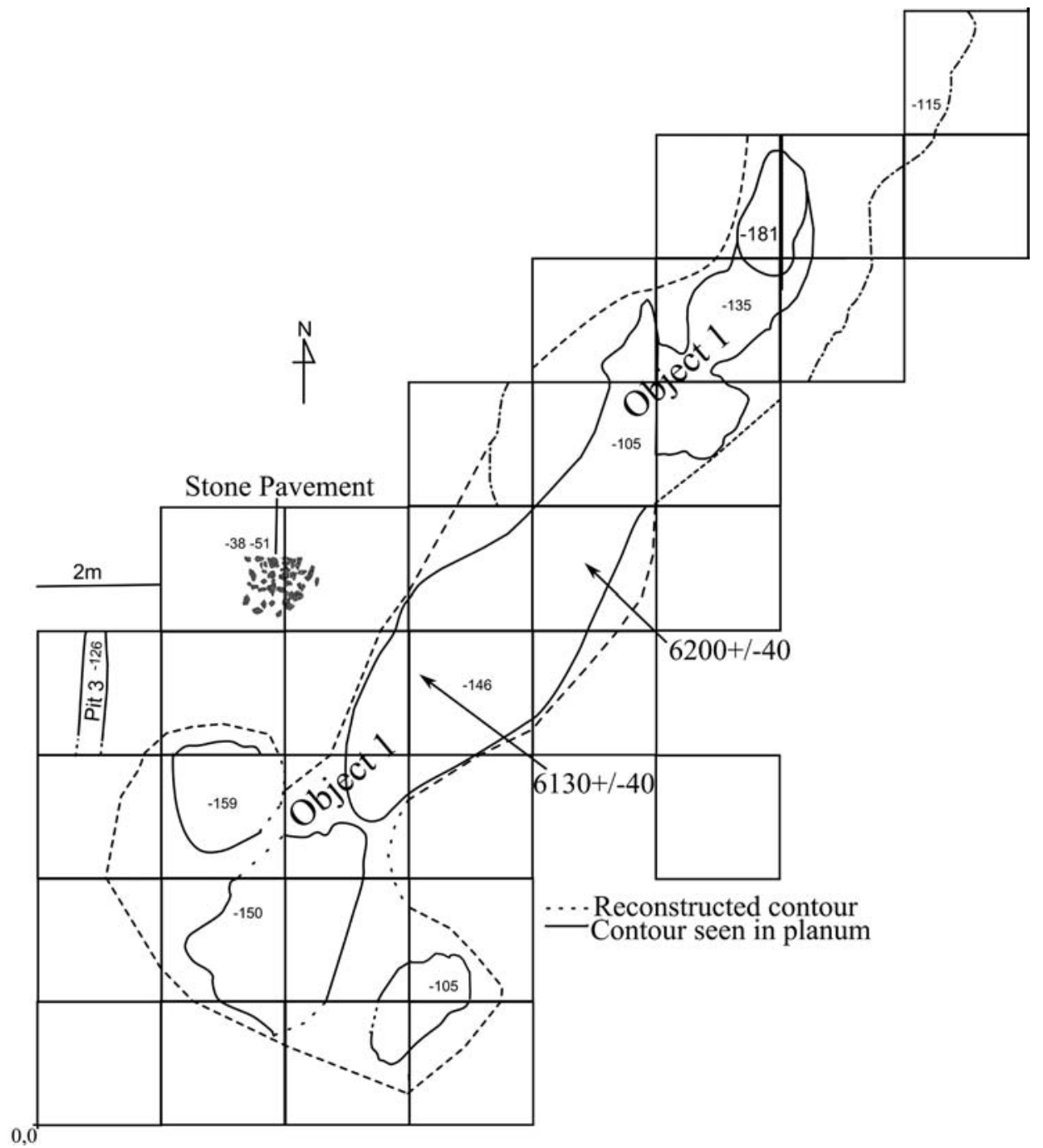

Fig. 3. Plan of Excavation No 1 with position of samples for radiocarbon dating

slowly with freshly broken things and by the natural erosion of its edges (D2), later it was covered by huge masses of garbage (bones, sherds, etc. - D1).

Pit 1 had a complex shape in terms of edges and bottom. There are certain parts of pit 1 where it cannot be found in yellow sediments but obviously it was not deep enough to enter them. These "pedestals" divide pit 1 into several sections - the long main body, almost perfectly oval in shape (pit 1/1) and two larger irregular depressions to the NE and 
SW (pit $1 / 2$ and $1 / 3$ ). The south-west section is bordered by two round pits, probably dug into pit $1 / 2$ filling when it was not completely filled. The north-eastern section included the deepest part of pit 1 (up to $-187 \mathrm{~cm}$ ( $210 \mathrm{~cm}$ from the modern surface). It was an elongated trough-shaped pit bordered by large stones. Some stones bear traces of use for grinding. They contained densely packed bones and bone fragments.

Pit 1 was dated by radiocarbon method to a time-span 5295-4960 calBC (Poz-67121, $6200 \pm 40$ BP and Poz-67554, $6130 \pm 40$ BP (Gouriveau et al., in preparation)).

\section{Stone pavement}

The scattering of stones was found to the NW of pit 1, some 1,5 m away. It was laid at a depth of $-48--62 \mathrm{~cm}$ (88-102 from modern surface). It was composed of flat and (probably) flattened small blocks of stone (mostly locally available quartzite). They seemed to compose a paved surface, fitting each other along breaks quite closely. Sometimes their shapes were probably intentionally changed in order to provide a better fit. The structure contained 3-4 characteristic LPC potsherds, leaving little room for doubt about its age. The pavement could lay on a "walking surface" of the LPC period.

Pit 3 is a narrow trench some $40-60 \mathrm{~cm}$ wide and $60-70 \mathrm{~cm}$ deep found on the western side of pit 1, close to the pit's part 1/2. It ran more or less in the same direction as pit 1. Pit 3 contained many pieces of burnt clay, charcoals, bone fragments and at least 3 large fragments of LPC vessels. We investigated only $2 \mathrm{~m}$ of the pit's length. It resembles closely the foundation trenches for LPC houses.

\section{Finds}

There are over 3000 potsherds, mostly found in pit 1 . They can be subdivided in four main categories:

I. fine-ware, with thin walls and evenly structured paste with little visible admixtures (sand, sometimes somewhat larger pieces of small pebbles, mica). A group of vessels contained graphite in the paste. It gave them a particular "silver" gloss;

II. coarse-ware, with walls that can be as thick as $25 \mathrm{~mm}$, rough surfaces and larger admixtures as temper;

III. red-ware made of lumpy, bristle paste, three-coloured (red-grey-red) in section;

IV. fine-ware, with lumpy structure in section, larger admixtures, but still finely evened, smoothed or burnished surfaces.

Fine-ware (I) includes 2/3 of found potsherds and over half of represented vessels if counted by preserved rims.

Fine-ware is mainly represented by globular or hemispherical bowls of a closed shape, $8-22 \mathrm{~cm}$ in diameter by a rim. They have light yellow, grey or dark grey well-polished outer surfaces and are well-smoothed from inside. There are 5 vessels with a complete or almost complete profile in pit 1 and pit 2 (Fig. 9: 1-5). 
Kamyane-Zavallia, the Easternmost Linear Pottery Culture Settlement Ever Excavated 259
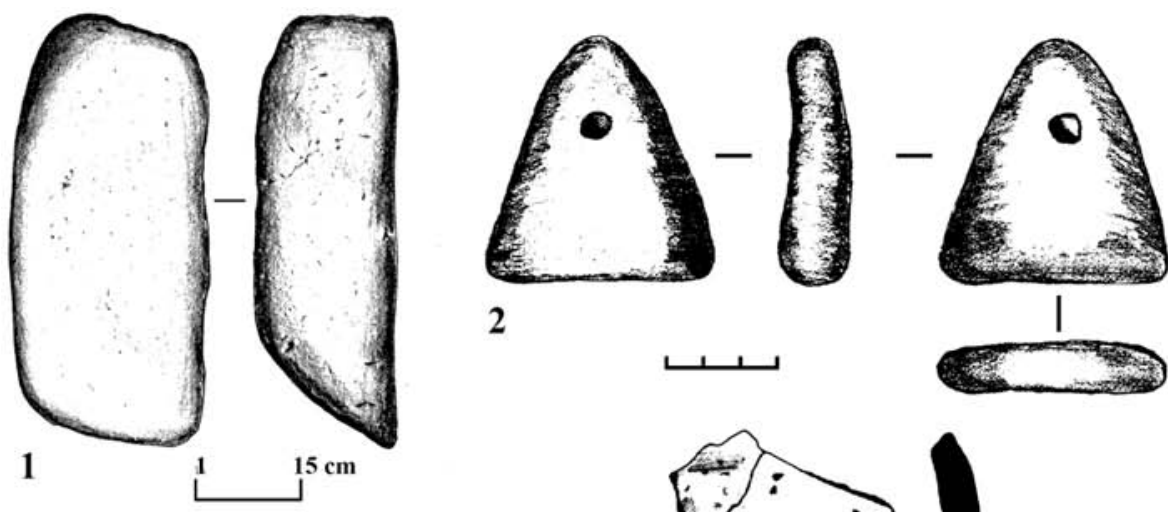

2
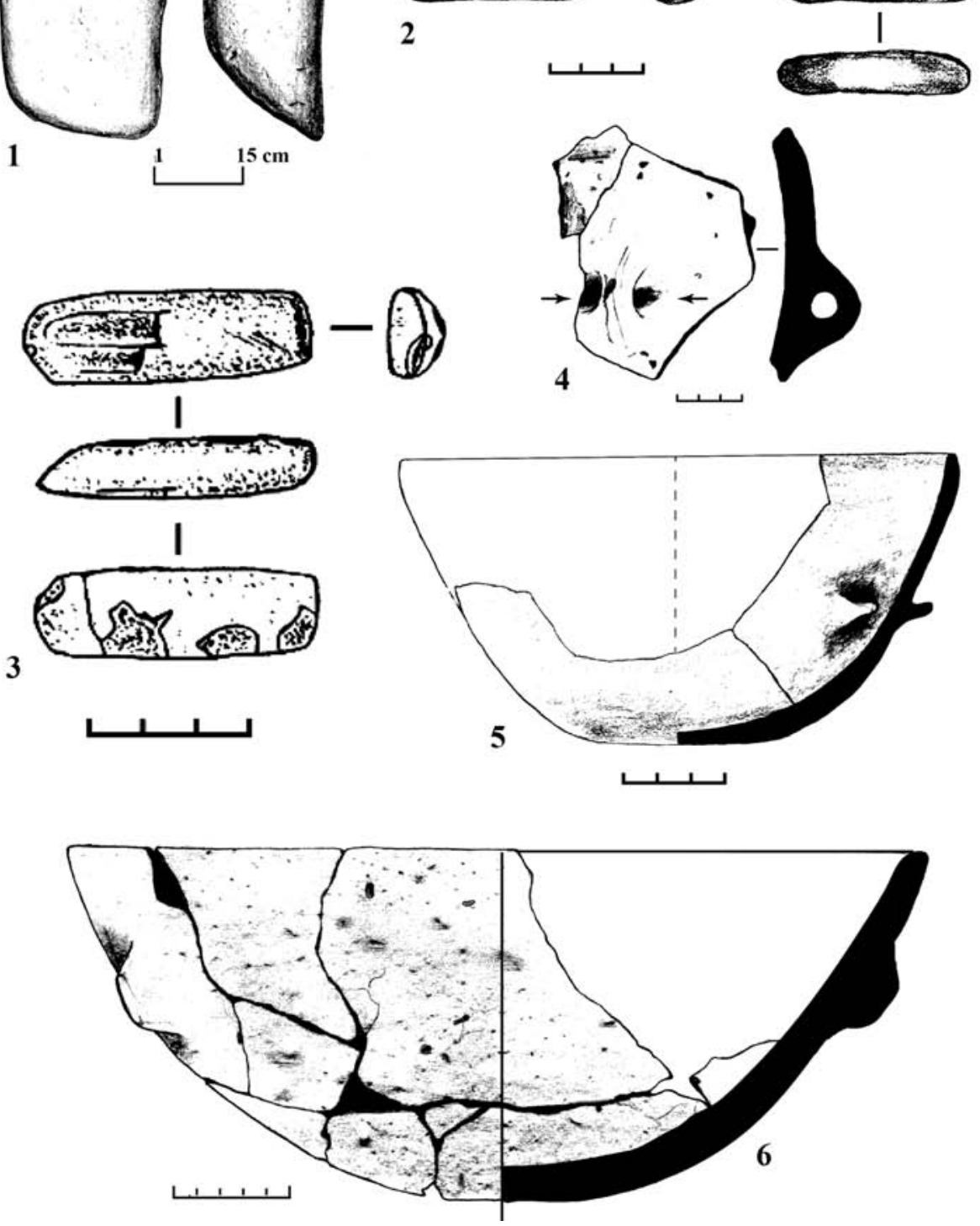

Fig. 8. Kamyane-Zavallia. Various finds: 1 - grinding stone; 2 - ceramic weight; 3 - Schuleistenkeil adze; 4 - handle on coarse-ware vessel; 5-6 - ceramic vessels 

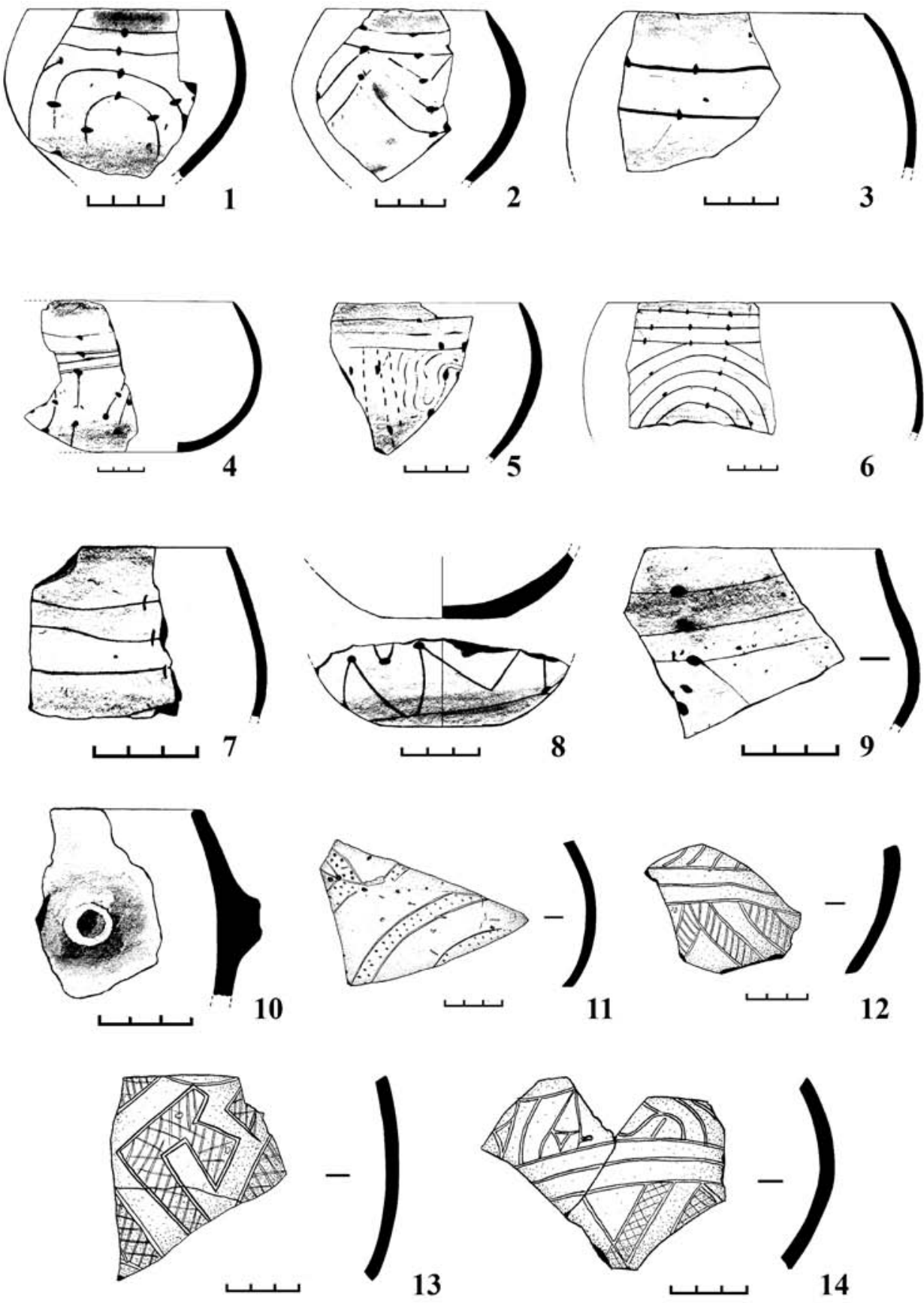

Fig. 9. Kamyane-Zavallia. Pottery. 1-9 Notenkopf-ornamented ware; 10 - knob decoration, 11 - "pseudoVinca stripe" decoration; 12-14 - potsherds ornamented in Dudeşti style 
Open bowls are not so numerous. The only almost complete specimen of this type stood $8 \mathrm{~cm}$ high, had a diameter of $16 \mathrm{~cm}$ at the rim and $6 \mathrm{~cm}$ at the bottom. It was decorated with four knobs and had a well-smoothed surface (Fig. 8: 5).

There are also necked vessels ("amphorae"?). They are represented by fragments of relatively narrow $(5-6 \mathrm{~cm})$ necks.

Some of the vessels stood on low, hollow pedestals.

The typical decoration pattern is 2-3 horizontal incised lines immediately below the rim and groups of straight or curved lines, triangles and arcs of circle running down a body of the bowl (Fig. 9: 1-4, 6-9). The lines are divided by small dots ("music notes").

There are some particular types of decoration: stripes of dots or hatches flanked by incised lines (Fig. 9: 11). The exact attribution of these stripes was a subject of debate. O. Larina treated them as Balkan influence and called a "Vinča stripe" (Larina 1999). N. Kotova pointed out that similar decoration is known in group Šarka in Silesia (Kovaliukh et al. 2007). They are a common, but never prevailing, component in Notenkopf complexes of south-east Poland (Kadrow 1990). Some potsherds have decoration that combine well-polished zones and intentionally made rough surfaces.

The coarse-ware (II) had different tempers in their paste and offhandedly finished surfaces. The commonest group (II-4) had coarse temper of stone fragments and pebbles which gave a rough appearance to the surfaces. The latter were often smoothed by fingers in a manner that left finger channels still visible. The surfaces, if even smoothed, still exhibit pieces of stones stretching from the walls. Large vessels with walls up to $25 \mathrm{~mm}$ thick were made in this technique. Some of them were necked and had handles. Decorations are knobs, finger imprints and nipples. Sometimes the neck of thick-walled vessel was decorated by plastic clay roll, divided by finger imprints. One vessel was ornamented by incised lines. The only preserved shape is represented by a large open bowl, $38 \mathrm{~cm}$ in diameter at rim (Fig. 8: 6).

The organically tempered ware (II-1) is not that common and shapes seem to be limited to relatively small open bowls.

There are also some potsherds (II-2) with paste tempered by fine mineral admixture (sand and mica) and well-smoothed surfaces. They are few and took an intermediate position between fine and coarse-ware (ceramica semi-fina of Romanian researchers) (Ursulescu 1990).

The red-ware (III) differs from the fine-ware by means of a typical paste which is badly burnt. The paste was not that carefully prepared and included some organic chaff inside. It made the section appear three-coloured with the outer parts burnt to red, while the middle part is still raw and grey and in general gave a lumpy outlook to the paste. There are some, usually undecorated potsherds of this ware and three miniature bowls made in this technique. The largest bowl is decorated with asymmetrically placed knobs.

The IVth category includes fine-ware made from paste that differs from typical Notenkopf fine-ware. The shapes cannot be reconstructed but some potsherds came from necked 

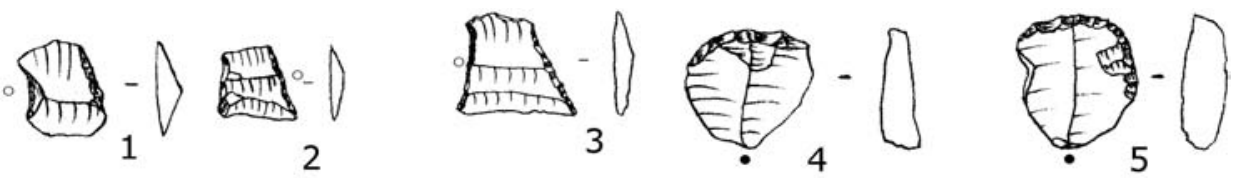

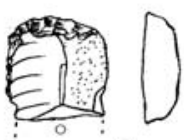

6

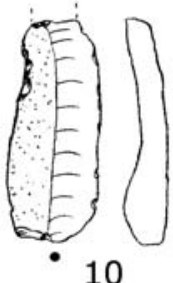

10

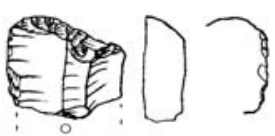

7

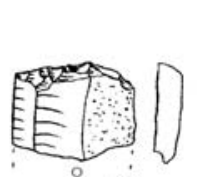

8

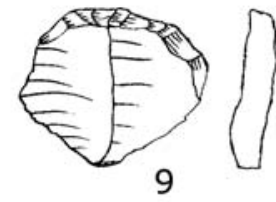

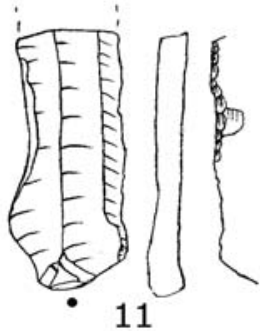
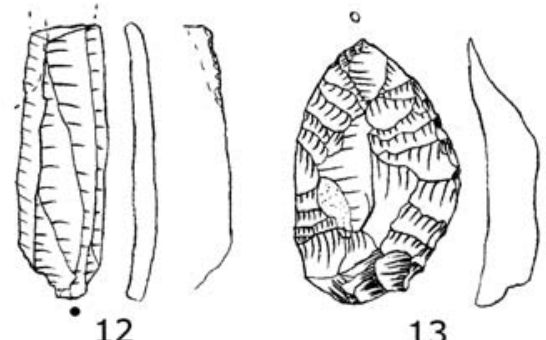

13

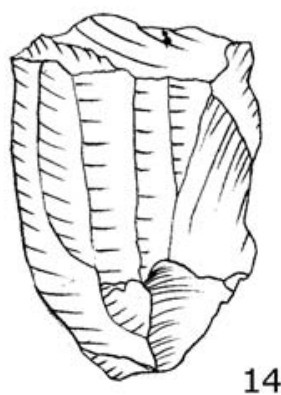

14
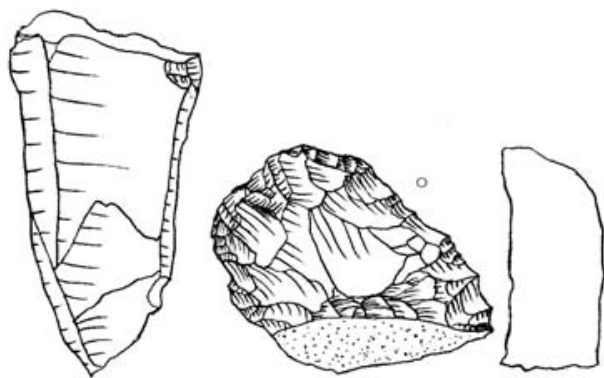

15

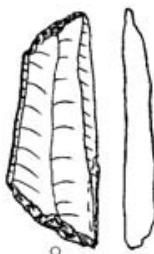

16

Fig. 10. Kamyane-Zavallia. Lithic implements

vessels and some - from vessels with prominent rib at the maximum width of the body. They are decorated in different style or styles. Some pieces have channelled surfaces. The channels are subcircular and appear to form a quite complex "concentric" pattern. Six shards originated from vessels with prominent rib that divided the body into two parts. The upper was decorated with curvilinear incised decorations. The lines are wider than usual for LPC and are done in a different style. The lower part is covered with complex angular figures filled with an incised net motif (Fig. 8: 12-14). Similar ceramics are known 
in Early and Late Dudesti, Dudesti/Vadastra or Vadastra I phases (Neagu 2003; Dragoman 2013; Thissen 2013) and to a lesser extent - in Boian-Bolintineanu (Hansen et al. 2012, 24) and Hotnitsa (Todorova and Vaisov 1993, 133) cultures or in contexts attributable to the Middle Neolithic in general (Hansen et al. 2012, 32).

There are some particular ceramic finds: ceramic weight (Fig. 8: 2), perforated items, rhyton-like vessel etc.

Pottery assemblage from Kamyane-Zavallia is characteristic for LPC culture of Ukraine and Moldova. Fine-ware decorations are indicative for Notenkopf II/III, or middle stage of music note phase in Ukraine and Moldova (Dębiec 2015). Variability of coarse-ware finds analogies in near-by Ukrainian sites (Okhrimenko 2009) and sites from Moldova (Larina 1999; 2006). Further research is needed in order to establish whether there are traces of interaction with the aboriginal pottery-bearing population.

The chipped stone assemblage numbers 690 items (from excavations and those gathered on the surface, 2011-2016). It is made from two varieties of flint with $90 \%$ of the artefacts made from dark-grey, transparent when thin, fine-grained, plastic flint. This raw material is not known in the vicinity of the site. There are outcrops of flints that have similar quality as far as Middle Dniester valley (some $180 \mathrm{~km}$ to NW) and in Volyhnia (over $250 \mathrm{~km}$ to the NNW) (Petrougne 1995). Some flakes were knapped also from pebble flint of poor quality that could be local.

There are 3 hammerstones made from pebbles of flint. Some (3) cores were re-used later as hammerstones. 12 cores are mostly prismatic or subprismatic with sub-triangular working surfaces (Fig. 10: 14). A core can be characterized as a flat core, resulting from maximum possible exploitation for serial production of blades and bladelets. There are also polyhedric cores for flakes and secondary cores for flakes (made on another thick flake).

Technological flakes include various products aimed at the installation of serial knapping. There are crested blades of various types: crete, sous-crete, semi-crete etc. They are mostly connected to the maintenance of a core in the course blade/bladelet detachment.

Blades and bladelets out-number microblades in contrast with local Recent Mesolithic lithic collections. Their butts are usually quite thick and large, sometimes without preparation and removal of overhang. The angle of percussion is around 85-95 degrees. Their sides and arrises are regular and parallel even if a little bit wavy. These observations are consistent with technical traces of punch technique rather than with pressure blades detachment or soft organic percussion.

The most common tools are end-scrapers which exhibit considerable formal variability (Fig. 10: 4-9). They are almost evenly split between items done on flakes and on blades. There are semi-circular, circular end-scrapers, microscrapers. The next most frequent are retouched blades/bladelets and their segments (Fig. 10: 10-11, 16). The less numerous categories include some side-scrapers (Fig. 10: 15), points and perforators (Fig. 10: 13), simple burins. Some blade segments bear characteristic oblique "sickle gloss" (Fig. 10: 12). 
"Sickle gloss" that is observed on some blades in local Kukrek and Bug-Dniester cultures is never oblique, but rather covers the very edge of a piece (Sapozhnikov and Sapozhnikova 2011). 5 trapezes were found in Kamyane-Zavallia. Two of them come from pit 1 and, thus, can be linked to LPC assemblages without any doubts. They are made of raw material of group 1. They are asymmetrical (Fig. 10: 1-3), done on narrow bladelets in a way that differs from techniques for production of Recent Mesolithic and Bug-Dniester scalene trapezes. They have retouched notch on an edge and oblique truncation on another. Similar asymmetrical microliths are known from Romanian sites of LPC (Păunescu 1970) and in particular, from Criş site of Sacarovca in Moldova (Dergaciov and Larina 2015).

In Ukraine and Moldova LPC had 2 local variants of lithic industry: Dniester (southeastern) and Vohlynian (northern). Dniester variant is characterized by presence of subconical cores, scalene trapezes, semi-circular end-scrapers on flakes etc. while they are absent in Vohlynia (Gaskevych 2003, 6). Kamyane-Zavallia is closer to the Dniester variant by typology of lithic assemblage.

Stone tools include pestles, hammerstones, and grinding stones. Grinding stones are numerous, both complete and in fragments. Some items are dubious but there are at least five stones with a well-polished working surface and having a navicular shape (Fig. 8: 1). They are made from local white stone (graphite quartzite) which can be found on the site itself and in a near-by modern quarry (as defined by L.Z. Skakun, "I. Franko" Lviv National University).

There is also a Schuleistenkeil adze (Fig. 8: 3). It is really small, 57x15 mm, and made from an unknown grey stone. There are no outcrops of such stone in the vicinity of the site. Probably it is a replica of real large Schuleistenkeil adze. It is the easternmost Schuleistenkeil so far known (Saile et al. 2016).

Animal bones belonged to both domestic and wild animals: red deer, swine, cattle (definition of O.P. Sekerska). There are bones with polishes indicating usage, worked bones, grooved antler and antler hammer (Fig. 11) in the collection.

\section{INTERPRETATION}

There are not so many sites of LPC to the east of the Dniester. Previously, they could have been treated as outposts of LPC in mostly alien territory, surrounded by local groups (Larina et al. 1999). Now, there are four-five settlements and five find spots in a limited area between Dniester and Southern Bug rivers in south-eastern outskirts of the hilly Podillian upland. Here they seem numerous enough to treat this space as an area regularly settled by LPC bearers. One can hypothesize that more LPC sites will be found here.

Kamyane-Zavallia is to date the only excavated site in the easternmost periphery of LPC and the limited area of excavations could perhaps hamper interpretation. However, the excavations yielded a "standard" LPC package": pottery decorated in Notenkopf style, ceramic weight, grinding stones, blade sections with characteristic gloss (so called "sickle 
inserts"), and the bones of domestic animals. The Schuleistenkeil adze was found on the surface of site and finds are characteristic for LPC residential sites.

Pit 1 is likely a typical "long pit" extensively known from Central Europe. They flank houses in multiple cases, sometimes similar pits stand alone. The latter are conventionally named "clay-extraction pits" (Lehmahnamegrube) (Birkenhagen 2003). The comparable pits are also found almost at each excavated settlement of LPC in west Ukraine and Moldova. They were usually interpreted as pit-houses in contrast with their interpretation in Central Europe (Passek and Chernysh 1963; Okhrimenko 2009). This incongruence arose partially from different taphonomic conditions: in Central Europe the long houses' layout are usually well visible in yellow loess and loess-like sediments immediately under the topsoil, while in Ukraine and Moldova, the LPC remains are covered by thick (sometimes over 1 meter) layers of black soil (chornozem) and deepened structures are difficult to detect in it. Recently, some of the "long pits" from old excavations were re-interpreted and are not treated as pit-houses anymore (Saile et al. 2016). Pits from Kotovane are supposed to flank the long house (Lenartowicz 2013) as far as "pit-houses" from some Moldovan sites do (Saile et al. 2016).

Pit 1 has a typical shape and orientation. Its irregular edges and bottom, elongated shape and rubbish fill makes it difficult to interpret it as "pit-house". It is either a long pit or clay-extraction pit of LPC. Pit 3 is a narrow trench that resembles the foundation trenches found in some LPC long houses. Pit 1 and pit 3, when treated together, seem to form a part of the typical layout of a LPC house - a "long pit" that stood along the wall and the part of the foundation trench for a wall. However, this layout should be opened completely by future excavations in order to state this with complete certainty. In this case Kamyane-Zavallia would yield the easternmost house of LPC.

LPC were not the first farmers to enter the territory of Moldova and western Ukraine. There are sites of Criş culture in the region as far as sites of local cultures equipped with pottery and acquainted with domestic crops (Bug-Dniester culture being the most relevant for our discussion) (Danilenko 1969).

Pit 1 yielded some potsherds that are very similar to Middle Neolithic ceramics from the Danube catchment (particularly of Dudesti culture). It indicates that LPC bearers interacted in a lively manner and over large distances (over $300 \mathrm{~km}$ from Kamyane-Zavallia to Danube) with early farmers from Balkans and Danube valley. Probably, the general similarity of material culture and lifeways simplified these contacts.

This fact is of paramount importance for interpretation of Early Trypillian expansion that came from eastern slopes of Carpathians (Precucuteni I sites) and covered roughly the area of easternmost periphery of LPC (Videiko 2004). LPC groups can be seen as precursors of Trypillia-Cucuteni people in "domesticating" the fertile black soils of Central Ukraine.

The lithic industry is done from non-local flint and finds little correspondence in complexes of local Mesolithic (Kukrek) and Bug-Dniester culture. The scalene trapezes could 
be treated as evidence of such influence. However, they found closer parallels in early farmer settlements from Moldova and Romania than in the roughly contemporary sites of Bug-Dniester culture.

LPC appear in the region as a migratory phenomenon with little connection to the local Mesolithic or Neolithic background. There is no "contact zone" where LPC characteristic traits are mixed with local traits. Kamyane-Zavallia is strikingly similar to its Central European contemporaries and is markedly different from any site of local Bug-Dniester culture, despite the fact that some sites of the latter are situated at a distance of only $5 \mathrm{~km}$ (namely sites of Zavallia and Zhakchik (Danilenko 1969). Few characteristics of KamyaneZavallia artefacts could be locally acquired, but even if this were to be proved true, it would not change the general "central-European" outlook of the assemblage. These facts correspond well with an explosive-like LPC expansion rather than with models which suppose that this spread was slow and involved certain stages of interaction with the autochthonous population.

Furthermore, the supposed differences between the "eastern variant" of LPC (limited by former borders of USSR) and typical Notenkopf sites of Central Europe seems to be exaggerated largely. The material culture of the easternmost ever excavated site of LPC resembles the latter to such an extent that gives us reason to doubt the very existence of an eastern "peripheral group" of LPC as a meaningful taxonomic category. Perhaps the best option would be to return to the primary definition of J. Pavuk, which encompassed the LPC sites to the east of Carpathians as a single entity (Pavuk 1969), rather than artificially divide the sites of South-Eastern Poland and Ukraine-Moldova.

\section{Acknowledgements}

The LPC potsherds were discovered in Kamyane-Zavallia by the Odessa archaeological museum survey team which included prof. I. Bruyako and V. Denisuk (besides the author). Excavations in Kamyane-Zavallia were carried out in the course of the didactic field expeditions of "I.I. Mechnikov" Odessa National University with the partial financial support of this institution. A local amateur archaeologist, O.S. Peresunchak, discovered Syne Ozero and contributed to our works at Gnyla Skelia and Kamyane-Zavallia. In 2013 a team from Regensburg University participated in the excavations (Prof. T. Saile, Dr. M. Dębiec).

The samples for radiocarbon dating were selected jointly with A. Salavert (Paris) and dating was supported by the program Action Transversale du Muséum "Les dynamiques socio-écosystémiques » (ATM DS-E). The archaeolozoological analysis was conducted by dr. O.P. Sekerska (“K.D. Ushinsky South-Ukrainian National Pedagogical University).

Prof. P. Biagi (Ca' Foscari University, Venice, Italy) kindly agreed to edit this text.

The author is extremely grateful to all of the above-mentioned persons for their help. 


\section{References}

Birkenhagen B. 2003. Studien zum Siedlungswesen der westlichen Linearbandkeramik. Bonn: Dr. Rudolf Habelt GMBH.

Bogucki P. I. 1988. Forest farmers and stockherders: early agriculture and its consequences in north-central Europe. Cambridge: Cambridge University Press.

Danilenko V. N. 1969. Neolit Ukrainy: Glavy drevneyshey istorii Yugo-Vostochnoy Evropy. Kyiv: Naukova dumka.

Dębiec M. 2015. Zur relativen Chronologie der Linienbankeramik in Südostpolen. Sprawozdania Archeologiczne 67, 31-56.

Dergaciov V. A. and Larina O. V. 2015. Pamiatniki kultury Crish Moldovy (s katalogom). Chişinau: Tipografia Centrala.

Dolukhanov P.and Shukurov A. 2004. Modelling Neolithic dispersal in northern Eurasia. Documenta Praehistorica 31, 35-47.

Dolukhanov P., Shukurov A. and Groneborn D. 2005. The chronology of Neolithic dispersal in Central and Eastern Europe. Journal of Archaeological Science 32, 1441-58.

Dragoman A. 2013. O biografie a ceramicii neolitice de la Vadastra. București: Editura Academiei Romana.

Dvorianinov S. O. 1982. Poselennia kultury liniyno-strichkovoy keramiki Mainova Balka na Odesschini. Arkheologiya 38, 93-5.

Gaskevych D. L. 1997. Vita-Poshtova 2 - naiskhidnishe poselennia z materialamy dunaiskoy neolitychnoy kultury. Arheologichni vidkryttia v Ukraini 1997-1998., 11-3.

Gaskevych D. L. 2003. Kremyaniy inventar neolitychnykh kultur Ukrainy. Kyiv: (unpublished Diss. of cand. of hist. sc.: 07.00.04).

Gaskevych D. 2011. A new approach to the problem of the Neolithisation of the North-Pontic area: is there a north-eastern kind of Mediterranean Impresso pottery? Documenta Praehistorica $38,275-90$.

Gouriveau E., Salavert A., Lebreton V. and Messager E. Early Neolithisation process in eastern Europe: first charcoal analysis from two sites in south-western Ukraine. In preparation.

Gronenborn D. 1998. Ältbankeramische Kultur, La Hoguette, Limburg, and ... What else? - Contemplating the Mesolithic-Neolithic transition in the southern Central Europe. Documenta Praehistorica 25, 189-202.

Hansen S., Toderas M., Reingruber A., Wunderlich J., Benecke N., Gatsov I., Marinova E., Muller M., Nachev C., Nedelcheva P., Nowacki D., Ropke A., Wahl J. and Zauner S. 2012. Pietrele an der Unteren Donau. Bericht uber die Ausgrabung im Sommer 2011. Eurasia Antiqua 18, 1-68.

Kadrow S. 1990. Osada neolityczna na stan. nr 16 w Rzeszowie na Osiedlu Piastów. Sprawozdania Archeologiczne 41, 9-76.

Kiosak D. 2013. Pivdenne Pobuzhzhia - chastyna arealu kultury liniyno-strichkovoy keramiki. In S. M. Gladun (ed.), IX Mykolaiv'ka oblasna kraeznavcha konferentsia. Istoriografia. Etnografia. Kultura. Novi Doslidzhennia. Mykolaiv: Iryna Gudyma, 75-7. 
Kiosak D. 2016. Mesolithic 'Heritage' and Neolithic in Southwest Ukraine. In H. Floss and R. Krauss (eds.), Southeast Europe before Neolithisation. Proceedings of the International Workshop within the Collaborative Research Centres sfb 1070 "RessourcenKulturen", Schloss Hohentubingen, 9 th of May 2014. Tübungen, 131-47.

Kiosak D., Bruyako I. and Denisyuk V. 2014a. Komplex arheologihceskikh pamyatnikov KamyaneZavallia v Srednem Pobuzhie: raboty 2011-2012. Tyragetia 8 [23](1), 73-88.

Kiosak D., Saile T., Debiec M. and Posselt M. 2014b. Rozkopky poselennia kultury liniyno-strichkovoy keramiki Kamyane-Zavallia 2013 roku. In D. Kozak (ed.), Arkheologichni doslidzhennia $v$ Ukraini 2013 roku. Kyiv: IA NAS Ukraine, 202-203.

Kovaliukh N. N., Kotova N. S. and Okhrimenko G. V. 2007. Novye dannye o khronologii neoliticheskih pamiatnikov Volyni. Materialy ta doslidzhennia z arkheologii Shidnoy Ukrainy. Vid neolitu do kimmeriytsiv 7, 3-7.

Kozłowski J. K. 1985. The Eastern Areas of the Linear Band Pottery Culture. In A. Kokowski (ed.), Memoires Archeologiques. Lublin: Zakład Archeologii UMCS, 51-70.

Kulczycka-Leciejewiczowa A. 1970. Kultura ceramiki wstęgowej rytej w Polsce. Zarys problematyki. In J. Kozlowski (ed.), Studies on the Linear Pottery Culture. Krakow: Polskie Towarzystwo Archeologiczne, 11-28.

Kulczycka-Leciejewiczowa A. 1979. Pierwsze społeczeństwa rolnicze na ziemiach polskich. Kultury kręgu naddunajskiego. In T. Wiślański (ed.), Prahistoria ziem polskich 2. Neolit. Wrocław: Ossolineum, 19-164.

Larina O. 2006. Neoliticheskaya keramika poseleniya Tetereuka Noue XV. Revista arheologică 2(1-2), 35-55.

Larina O. V. 1999. Kultura lineyno-lentochnoy keramiki Pruto-Dnestrovskogo regiona. Stratum plus 2, 10-140.

Larina O. V. 2010. Inceputurile Economiei Productive. Neoliticul. Oranduirea Gentlico-Tribala. In V. Dergaciov (ed.), Istoria Moldovei: Epoca preistorica si antica: (pana in sec. V). Chisinau: Tipografia Centrala, 177-218.

Larina O. V., Sapozhnikov I. V. and Petrenko V. G. 1999. Kultura lineyno-lentochnoy keramiki Dniestrovsko-Bugskogo mezhdurechia. Starozhytnosti Pivnichnogo Prychornomoria i Krymu 7, 10-21.

Lenartowicz O. V. 2013. Kultura liniyno-strichkovoy keramiki u baseyni verkhniogo at seredniogo Dnistra i Zahidnogo Bugu. Kyiv (unpublished Avtoref. cand. ist. Nauk).

Neagu M. 2003. Neoliticul mijlociu la Dunărea de Jos cu privire specială asupra centrului Munteniei. Călărasşi: Muzeul Dunărea de Jos.

Okhrimenko G. V. 2009. Kamyana doba na terytorii Pivnichno-Zahidnoy Ukrainy (XII-III tys. BC). Lutsk: VAT "Volyns'ka oblasna drukarnia".

Passek T. S. and Chernysh E. K. 1963. Pamitniki kultury lineyno-lentochnoy keramiki na territorii SSSR. Svod arheologicheskih istochnikov, Б I-II, 5-42.

Păunescu A. 1970. Evoluția uneltelor şi armelor de piatră cioplită descoperite pe teritoriul Romậniei. Bucureşti: Editura Academiei Republicii Socialiste Romậnia. 
Pavuk J. 1969. Chronologie der Zelizovce-Gruppe. Slovenska archeologia 17(2), 269-367.

Petrougne V. F. 1995. Petrographical-lithological characteristics of stone materials from the late-Tripolye cemeteries of Sofievka-type. Baltic-Pontic Studies 3, 190-9.

Price D. T., Bentley R. A., Luning J., Gronenborn D. and Wahl J. 2001. Prehistoric human migration in the Linearbandkeramik of Central Europe. Antiquity 75, 593-603.

Saile T., Dębiec M., Posselt M., Țerna S. and Kiosak D. 2016. Zur Bandkeramik zwischen Pruth und Südlichem Bug. Praehistorische Zeitschrift 91, 1-15.

Sapozhnikov I. V. and Sapozhnikova G. V. 2011. Kamennyj vek Severo-Zapadnogo Prichernomoria. Stratum plus 1, 15-149.

Stanko V. N. and Kiosak D. 2010. The Late Mesolithic Settlement of South-Western Ukraine. Atti Societa Preistoria e Protostoria, Friuli-Venezia-Giulia 17, 24-100.

Stanko V. N. and Smolianinova S. P., 1974. Razvedki v Savranskov i Liubashevskom raionakh Odesskoy oblasti in 1974. Odessa (unpublished elaboration stored in Archive of Odessa Archaeological Museum).

Telegin D. J. 1979. Novye pamiatniki kultury lineyno-lentochnoy keramiki na Ukraine. Sovetskaya Arheologiya (2), 229-34.

Telegin D. J. 1985. Voprosy kulturno-khronologicheskogo chlenenniya i sinkhronizatsii pamiatnikov neolita. In D. J. Telegin (ed.), Arheologiya Ukrainskoy SSR 1. Pervobytnaya Arheologiya. Kyiv: Naukova dumka, 110-118.

Thissen L. 2013. Middle Neolithic Ceramics from Teleoro3, Southern Romania. Buletinul Muzeului Judetean Teleorman. Seria Arheologie 5, 25-123.

Todorova H. and Vaisov I. 1993. Novokamennaiato epoha v Blgaria (kraiat na sedmo-shesto khiliadoletie predi novata era). Sofia: Nauka i Izkustvo.

Tovkailo M. T. 2014. Neolitizatsiya Yugo-Zapadnoy Ukrainy v svete novykh issledovaniy poseleniya Gard. Stratum plus 2, 183-245.

Ursulescu N. 1990. La civilisation de la ceramique rubanee dans les regions orientales de la Roumanie. In V. Chirica and D. Monah (eds.), Le Paleolithique et le Neolithique de la Roumanie en contexte europeen. Iaşi: Editura Universității Al.I. Cuza, 188-223.

Videiko M. Y. 2004. Periodyzatsia trypilskoy kultury. In M. Y. Videiko and N. Burdo (eds.), Entsyclopedia trypilskoy tsyvilizatsii 1. Kyiv: Korporatsia „Industrialna Spilka Donbasu” ZAT „Petroimpex", 77-84.

Zakharuk J. N. and Telegin D. J. 1985. Kultura lineyno-lentochnoy keramiki. In D. J. Telegin (ed.), Arheologiya Ukrainskoy SSR 1. Pervobytnaya arkheologiya. Kyiv: Naukova dumka, 126-33.

Zaliznyak L., Tovkailo M. T., Man'ko V. O. and Sorokun A. A. 2013. Stoyanky bilia khutora Dobryanka ta problema neolityzatsii Bugo-Dnistrovskogo mezhyrichia. Kamyana doba Ukrainy 15, 194-257. 
